\title{
VALIDATION OF QUANTITATIVE PCR FOR ONION WHITE ROT DIAGNOSIS
}

\author{
D. NICOL, H.J. RIDGWAY and A. STEWART \\ National Centre for Advanced Bio-Protection Technologies, \\ Lincoln University, Canterbury, New Zealand \\ Corresponding author: nicold@lincoln.ac.nz
}

\begin{abstract}
Onions are New Zealand's largest fresh vegetable export commodity, returning revenue of $\$ 101 \mathrm{M}$ per annum. Production in many regions is becoming uneconomic due to the presence of Allium white rot. The causal agent, Sclerotium cepivorum Berk., is a soil-borne pathogen that survives as small sclerotia, usually $0.25-0.6 \mathrm{~mm}$ diameter, formed on the tissue of host plants. These sclerotia can survive in the soil for a number of years, reinfecting subsequent crops. Traditionally, detection of inoculum in the soil relies on laborious soil sieving and counting of sclerotia. The current research reports on the development of a quantitative PCR method for detection of propagules of Sclerotium cepivorum in soil using a species-specific probe. In preliminary trials, quantitation has proven accurate and sensitive, with 1-100 sclerotia detected in $20 \mathrm{~g}$ of soil. The incorporation of a sucrose centrifugation and sieving step shows potential for later diagnostic use, reducing the amount of soil up to 500 fold, whilst maintaining $96 \%$ recovery of sclerotia. Suggestions are made for further enhancement of this research, and development of a diagnostic service for onion growers is discussed in relation to disease prediction and indexing.
\end{abstract}

\section{"MITOTYPING" - AN EFFECTIVE STRATEGY TO IDENTIFY AFRICANISED HONEYBEES FOR NEW ZEALAND BIOSECURITY?}

\author{
K.F. ARMSTRONG ${ }^{1}$, P.W. HOLDER ${ }^{2}$ and W. CHINN ${ }^{1}$ \\ ${ }^{1}$ National Centre for Advanced Bioprotection Technologies, \\ PO Box 84, Lincoln University, Canterbury \\ ${ }^{2}$ National Plant Protection Reference Laboratory, \\ Ministry of Agriculture and Forestry, P.O. Box 24, Lincoln, Canterbury \\ Corresponding author: armstron@lincoln.ac.nz.
}

Africanised honeybees are typically defensive, tending to sting, swarm and abscond. They are difficult to manage, rapidly displace other hived bees and are undesirable to the beekeeping industry. New Zealand faces the threat of their accidental introduction, including through future demand for re-stocking hives with Varroa-resistant queens from overseas. Unfortunately morphological identification of Africanisation is unreliable. An alternative USDA molecular "mitotyping" protocol (PCR-RFLP of 16S and COI mitochondrial genes) was used recently to identify 'dark' bees swarming at Lyttelton harbour. Those bees produced a west European (Apis mellifera mellifera) profile, consistent with local feral bees compared to a managed Balclutha colony that gave the expected European lineage (A. m. ligustica) profile. However 'dark' bees from Wellington, characteristic of west European lineage, gave an east European profile, as did an Africanised North American colony (A. m. ligustica $\mathrm{x}$ A. m. scutellata). This is consistent with hybridisation to the more abundant east European managed bees, but highlights the limitation of maternally inherited mitochondrial DNA; paternally derived African genes could go undetected. To improve New Zealand's capability of identifying Africanised honeybees, additional nuclear DNA markers, evaluation of the bees already here and inclusion into a universal platform for DNA diagnostics are considered. 